\title{
FORMING OF THE MEMORY OF ANDRE] HLINKA IN THE CATHOLIC ENVIRONMENT UP TO 1938
}

\section{ABSTRACT}

The anchoring of Andrej Hlinka in the consciousness of the Slovak society went through a number of changes. In the period of the existence of Austro-Hungary, the time of increasing Magyarization, Hlinka, as a result of the tragedy in Černova, he became a symbol of the struggle of the Slovaks for national freedom. Hlinka gained the aureole of a martyr fighting for the right of the Slovak nation for its separate existence. After the foundation of the Czechoslovak Republic, Hlinka became the leader and Father of the Slovak nation, fighting for a greater freedom of the Slovak nation, this time in the form of autonomy within the new state. In the 1930s it was primarily his followers who nurtured the cult of Hlinka's person, which flourished at the time of his seventieth birthday celebrations. Hlinka was at the time perceived as the greatest living Slovak and the man who had the greatest merit in reforming the Slovaks into a modern nation.

\section{KEYWORDS:}


Andrej Hlinka represents one of the most outstanding personalities in the Slovak history of the end of the 19th and in the first half of the 20th centuries. He first entered the Slovak social awareness in a significant way during his activities as a parish priest in Tri Sliače (today's Liptovské Sliače) from 1892. He left an indelible stamp on the Slovak historical consciousness particularly in 1905-1908, when his name was connected with the founding of the Slovak People's Party in 1905, a political trial in 1906, and chiefly in relation to the tragic events in Černova, all of which made Hlinka a symbol of intractability, uncompromisingness, and fidelity to the Slovak nation. He became such a significant figure in Slovak society and resistance to Upper Hungary's nationalist policy that the Scottish writer Robert Seton-Watson used his photograph on the cover of his book Racial Problems in Hungary, in which, at the height of Magyarization pressure in Upper Hungary, he made the Slovak question visible throughout the world. As Seton-Watson himself stated:

When fifteen years ago I wrote my work, The Nationalist Question in Hungary, some people reproached me for putting the likeness of Hlinka in the frontispiece of the book. But at that time I believed, and I maintain even today, that at that moment he was the most characteristic figure in the struggle of the Slovak nation against Magyarization. Among other things, he represented that Slovak devotion to religion and embodied the outraged moral feeling that characterized Slovaks in the new period.

The process of anchoring his memory in the social and historical consciousness of those times was extensive, differentiated and yet motivated by ideological/ political factors.

During his life, Hlinka became for many Slovaks a symbol and a hero. This process of creating a hero in the historical memory depends to a significant extent on the society and on the ideological needs of the group that the hero is meant to represent. Within the selected group, he performs a legitimizing and an agitating function at the same time ${ }^{2}$, so that forming a historical memory is influenced primarily by the powerful. Alongside the official memory, there is also an individual memory which incorporates the memories of groups such as the family, the community, nation, class, church, and so on. An attempt at forming the official and also the individual historical memory of Andrej Hlinka in the Catholic environment on the basis of interpretations of selected issues and sources is the specific goal of this text. In light of the expansive-

1 R. W. Seton-Watson, “Nábožensko-cirkevný problém“. In: Lidové noviny, (32), 27 Jan 1924, is. 49, p. 2.

2 K. Hollý, "Formovanie historickej pamäti o Andrejovi Kmetovi, Forum historiea. In his study Karol Hollý follows from the works of the Polish historian Jerzy Topolsky; e.g., J. Topolski, "O pojęciu bohaterów w historii". Przegląd Humanistyczny, 1996 (40), No 1 (334), p. 19-26, in paticular p. 19-23. 
ness of the topic, the literature and the sources, the work will concentrate on three selected areas. The forming of a historical memory regarding Andrej Hlinka will follow from the period after the Černova events in 1907, when the building of a cult around Hlinka in the Slovak society began; then we will look at the picture of him created in the years following the foundation of the Czechoslovak Republic, while the third part will focus on the 1932-1938 period, the years of radicalization of the attempts to implant the Slovak autonomy in the First Czechoslovak Republic. This will mean looking closely at the events which formed the memory of Hlinka in those stated periods. The restricted space within this anthology does not allow for a more extensive detailed analysis, but the presented text will hopefully map out the possibilities for research into the forming of the Andrej Hlinka's memory. The work principally springs out of articles published in the period newspaper Slovák, the central print organ of the Slovak People's Party, which began publishing on January 16, 1919.

Hlinka's life and work contributed to the forming of the Slovak history in the first decades of the 20th century, whether under Hungary or within the Czechoslovak Republic. Through his attitudes and opinions, Hlinka had a great influence on the general public. His ideological/political starting points and the positive and negative features in the course of his life were crystallized by the opposing camps of Hlinka's supporters and detractors (without regard to religious faith) which finally contributed to the historical memory of, and the building of a cult to, his personality. ${ }^{3}$ The various opinions on Hlinka's personality and the creation of its multiple images result from differences within the Slovak nationalist community as well as from internal divergences within the seemingly monolithic clerical wing of the Slovak political structure. Even during Hlinka's lifetime, an idealization, mythification and sacralisation of his personality were taking place, which was projected into the formation of the historical memory of Andrej Hlinka.

\section{ČERNOVÁ - THE BEGINNING OF THE FORMING OF AN- DREJ HLINKA'S HISTORICAL MEMORY}

In 1907 a new wave of Magyarization was launched in Upper Hungary. The socalled Appony School Laws were issued, which became a symbol of the Magyarization intentions of the coalition government. Aggression against non-Hungarian nation-

3 It was P. Macho who dealt with Andrej Hlinka and his anchoring in the Slovak historical memory in a number of his studies, "M. R. Štefánik a A. Hlinka v básnických a komemoratívnych textoch. Historická osobnost' ako národný symbol a jeho štylizácia”, Studia Academica Slovaca, 2005 (34), p. 367-395; P. Macho, "Reflexia Andreja Hlinku v protestantskom prostredí”, Milan Rastislav Štefánik v hlavách a v srdciach. Fenomén národného hrdinu v historickej pamäti, Bratislava 2011, p. 136-146. 
alities and their national-emancipation activities culminated in the bloody events in Černova (part of Ružomberok) in October 1907, which led to the suspension of A. Hlinka and the subsequent Ružomberok trials. Hlinka's banishment related to his participation in the 1906 pre-election campaign, which his superior, the Spiš bishop Alexander Párvy, had forbidden. For disobeying the command, the bishop punished him through another ban on performing his priestly functions, which Hlinka did not agree to. The conflict between Párvy and Hlinka was in the end sent to the Vatican for resolution. In between, however, Hlinka was involved in an uprising in jail and even in the court. During the 'demagogic and anti-Pan-Slav' course of the trial, Hlinka gained the aureole of a martyr and a fighter for the Slovak national rights. ${ }^{4}$ The Ružomberok trial acted as a precursor of the Černova events.

The inhabitants of Černova, with their own finances, had a new church built and wanted Hlinka to consecrate it, which, on account of his suspension, he could not do. Although the population was willing to wait until Hlinka's suspension was lifted, both the secular and the sacral authorities ordered the church to be consecrated. On the day of the consecration, October 27, 1907, the inhabitants demonstrated resistance that the Upper Hungarian gendarmes settled by killing 15 people and wounding dozens more. The tragedy in Černova revealed in full detail the national suppression of the Slovaks. It so became a symbol of the Upper Hungarian regime's repression prior to the First World War and one of the key reprisals against the Slovaks. It called forth an immense response from abroad and increased interest in the Slovak issue. From its beginnings, this tragic incident was associated with the name of Andrej Hlinka, and in fact it was Černová which started the building up of Hlinka's cult, which contributed to securing his place in the Slovak historical memory.

The idealization and mythification of Andrej Hlinka in the Slovak community following the Černová trial resulted from the fact that the pro-government press blamed him in particular for the tragedy:

He was aware of the affection his countrymen had for his person and he knew of the unbridled hatred of a significant part of them to anything that related to Magyarization and which nurtured and stirred up their exaggerated nationalist sensibilities. He whipped up these sensibilities both in Černova and in Ružomberok... He united their national convictions with their religious feelings. And the people, brought to such a mental state by Hlinka, fanatically devoted themselves to his service and by common resolution declared that they would stop the consecration of the church even at the cost of their own blood.

4 Ad process see, e.g. D. Kováč, "Charizma, triumfy a krok vedla. Súdne procesy Andreja Hlinku”, Storočie procesov, Bratislava 2013, p. 40-50.

5 K. Sidor, Černová (1907-1937), Bratislava 1937, s. 74. 
Despite the fact that Hlinka was absent from the blessing of the church, the accusation held him responsible for the entire event: "The entire insurrection was the work of Hlinka. The responsibility for the bloodshed falls directly on him...” This was a response to Hlinka's words of less than one month before the tragedy. Hlinka then reportedly said: "Blood will flow if you bless the church without me." However, the prosecution was not able to confirm this statement. ${ }^{6}$ The 1906 Ružomberok trial and Černová in the following year represented an impulse for the widening and solidifying of Andrej Hlinka's memory:

The Hungarian lawyers based the accusation against the people of Černova on the affirmation that Andrej Hlinka himself, by his modest letters, set the locals against the spiritual and temporal authorities. He was identified as the spiritual leader of the Černova insurrection. In contrary to this affirmation stands the fact that six weeks before the Černova incident Hlinka travelled incognito to Morava and communicated his address to no-one. He wrote not one line to Černova, and so could not be considered as the spiritual leader of the Černova insurrection. 'Spiritual leader of the insurrection' was an injustice that the blinded Hungarian gentlemen visited on the Černova people and on its native son, Andrej Hlinka?

Pro-Hungarian journalism of the time not only identified Hlinka as the deviser of the Černová incident, but also claimed the motive of his action was the desire for material gain: "For us Hlinka is a kind of wild animal who should immediately be shot. He speaks of himself as if he was sent by God to save the Slovaks. But he is an ordinary villain. Yes, he is a scoundrel... The Černová catastrophe brought Hlinka a lot of money." The authors of these articles not only attributed the role of the main instigator of the Černová bloodshed to Hlinka, but went on to designate him as the sole fighter for the right of the Slovak nation to self-determination. This was enough to cause the Slovak community to focus on A. Hlinka and to implant his positive image in the memory of his contemporaries. The consequent trial addressing the Černová event prepared the ground to hyperbolize the aureole of Hlinka as a martyr in the struggle for the right of the Slovak nation to its own existence within the Upper Hungary state. The attacks of the pro-Hungarian press against Andrej Hlinka and the later verdict of the Ružomberok trial started off a campaign against Hlinka. Accordingly, a number of Slovak intellectuals and representatives of the Slovak national movement, without regard to their religious background, stood up in Hlinka's defence.

6 “Process proti Černovčanom”, Národnie noviny, 13 Feb 1908 (39), No. 19, p. 2.

7 K. Sidor, Andrej Hlinka, Bratislava 1924, p. 17.

8 A. Kolísek, Andrej Hlinka. (Odtlačok článku s Andrejom Hlinkom z časopisu Rozvoj 1924, č. 1-2), Bratislava 1924, p. 9. 
Along with his Slovak backers, Hlinka also found his defenders beyond the borders of Upper Hungary. Hlinka gained perhaps his most significant moral defence from the Czech Roman Catholic priest Alois Kolísek, who in his brochure overturned the most frequent accusations against him.

The investigation, the trial of the people of Černova, and the polemics on both sides of the barricade became the source of legends which rooted Andrej Hlinka in the consciousness of his peers and in the historical memory of later generations in both national camps. ${ }^{9}$

The motivation of the accusers in the trial was obvious. They intended to show that from its very beginnings the tragedy was accompanied by a nationalist undertone and by the bloody intentions of the crowd of Slovak faithful. According to the prosecution, this undercurrent did not spring from the Hungarian government powers but from the Slovak side, including their leading personalities. So an important task for the Cernova trial was the revelation of the spiritual organizers of the incident who stood in the background of the entire event. The prosecutors claimed these were not only local authorities, but insisted that the chief instigators were the "Pan-Slav firebrands", which meant the leaders of the Slovak national movement. Holding first place among them was none other than Andrej Hlinka, along with his right hand in Černova, his sister Anna Fullová. This charge later served to increase the share of Hlinka and his family in the action and led to an identification with Hlinka's fate among the Slovak public. Emphasizing Hlinka's part in the tragedy was designed not only to compromise him personally but also to blacken the Slovak national emancipation movement and the Slovak-Czech collaboration, as claimed the articles in another government organ, the Budapest-based Slovak News:

Hlinka stirred up the peaceful inhabitants of the municipality through his blood brothers, and we must acknowledge that he roused them very carefully so that human justice could not bring responsibility to his door. In fact he was so careful that on the day of the terrible blood-letting he was not even at home... when everything was underway as he himself wanted, Andrej Hlinka jumped onto a train and travelled off to the Czech and Moravian territory. And when the news of the bloody riot spread, Andrej Hlinka allowed himself to become a celebrity among the Czechs: he held lectures here and there in Czech and Moravian towns: about himself and everything that could interest the Czech zealots. We can only imagine all Hlinka spoke about, how he incited the Czech fanatics! $!^{10}$

9 R. Holec, Tragédia v Černovej a slovenská spoločnost', Martin 1997, p. 171.

10 Quoted according to: R. Holec, Tragédia v Černovej a slovenská spoločnost', Martin 1997, p. 165. 
Further information on Hlinka was intended to form a negative image of him as a representative of the Slovak nationalist movement among the general public, mainly foreign. The official accounts of the trial placed Slovaks in a bad light, and were directed to reducing the share of the state authorities in the blame for the Černova massacre. Emphasizing the fact that the local Slovak faithful were the initiators of the tragedy was intended to erase the unfavourable impression that the Černova incident had provoked abroad. A number of arguments were used to compromise A. Hlinka. Anti-Slovak journals went so far as to point to Hlinka's alleged material motivation for the entire event:

Money, that is his only goal! He goes to Czech and Moravia and shows himself just as the Bosnians show us a bear... Because he is an unfilled bag, and his grasping stinginess knows no end... The Černova catastrophe brought Hlinka heaps of money! And now Hlinka sits in Segedín in a warm room on a soft sofa, washes himself with wine, wipes himself with liver paste and reads the newspaper..."

According to another pro-government newspaper, the Banska Bystrica Krajan, the desire for financial gain also led Hlinka's sister Anna Fullová to initiate the bloody events:

The invisible head of the riot in Černova is Hlinka, but the visible head is his sister, Anna Hlinka, married name Fulla... This woman, knowing that her brother Ondrej would sock nothing away if he continued without a parish, wanted at any cost to force the bishop into returning his parish to him. She knows very well that the Czechs, the Moravians, and the American Slovaks will finally realize that Hlinka does not stand up for the Slovak language or the Slovak people, that he seeks only to fill his pockets and build his fame, and that they will cease to pour money on Hlinka and then she will have no hope that Hlinka will bequeath her anything. She knows that in our country they will subsequently be paying closer attention to Hlinka, and the layabout Hlinka has a good harvest only from the insurrection, because he is not capable of work - so she is afraid that she will have to undertake the care of her brother for free. ${ }^{12}$

However, similarly fabricated statements against Andrej Hlinka did not fulfill the expectations of the governing power; quite the contrary. His support increased not only among the Slovaks, but also abroad.

Although the prosecution in the Černova trial managed to bring in a verdict for the bloodshed against the Slovak activists and their spiritual head Andrej Hlinka

11 R. Holec, Tragédia v Černovej a slovenská spoločnost', Martin 1997, p. 165

12 A. Kolísek, Andrej Hlinka. (Odtlačok článku s Andrejom Hlinkom z časopisu Rozvoj 1924, č. 1-2), Bratislava 1924, p. 10. 
and to convict several participants in the consecration to a total of almost 37 years in prison, Andrej Hlinka, thanks to the made-up accusations, strengthened his position as the leader of the Slovak nationalist movement and progressively formed himself in the memories of his contemporaries as a symbol of intractability and faithfulness to the Slovak nation. Hlinka himself contributed to the perception of himself as a leading representative of the Slovak nation following Černova by returning to the event in his newspaper articles appearing in the Slovák daily and referring to the injuries visited on the Slovak nation for which the governing power was blaming Hlinka: "A complete catastrophe. The poor, god people fell before the consecration. The Hungarians have accused me of murder..., even though they know I had not even been in Slovakia in the two weeks preceding the consecration!"13 In Hlinka's view, Černová contributed to the liberation of the Slovaks from under the Hungarian yoke and set the fundaments for Slovakia's freedom. Hlinka at the same time brought up the fact that by means of the tragedy the public throughout the Habsburg monarchy and abroad became informed of the unhappy situation of the oppressed Slovak nation in multinational Upper Hungary. Due to Černova the attention of foreign journalists was turned to the situation of Slovaks in Upper Hungary and to their defence. Writers like the Norwegian author Björnstjern Björnson and Robert William Seton-Watson, writing under the pseudonym Scotus Viator, placed the Slovak issue before the eyes of the European public. According to Hlinka, "out of the warm and fresh blood of the Slovak martyrs grew the Slovak liberty." ${ }^{\prime \prime 4}$ Hlinka himself many times emphasized that precisely due to Černova he had become the political leader of the Slovak nation.

By means of Černova, Hlinka's image as the saviour of the Slovak nation and the symbol of their repression, one who even under the threat of prison did not hesitate to defend Slovaks at the peak of the Magyarization policy of the Upper Hungary and Hungary governments, was fixed. Hlinka did not recognize the existence of a united political Hungarian nation in Upper Hungary, "but he and his party burned for the Slovak nation in the ethnic and political sense of the word." ${ }^{\prime 6}$ For his attitude he had to face persecutions, first suspension from the position of the parish priest in Černova, and later, in 1907, two years and nine months in prison due to the conflict with his bishop, Alexander Párvy. Prison did not break him; on the contrary it strengthened Hlinka's position as a fighter for the right of the Slovak people to self-determination:

13 Hlinka, A., "Na černovskom cintoríne”, Slovák, 27 Oct 1923 (5), No. 234, p. 1.

14 Hlinka, A., "Na černovskom cintoríne”, Slovák, 27 Oct 1923 (5), No. 234, p. 1.

15 Hlinka, A. "Otvorený list na dr. Augustína Rátha, rektora bratislavskej univerzity”, Slovák, 18 Feb 1922, (4), No. 40, p. 1 .

16 Sidor, K., “Uväznenie Andreja Hlinku pred 30 rokmi”, Slovák, 28 Jun 1936 (18), No. 147, p. 1. 
Before our eyes stands a politician who does not say: 'I am willing to lay down your life for my cause.' Before us stands a politician who with every cell in his body and with his whole spirit cries: 'I am ready to lay down my life for your cause. ${ }^{, 17}$

Historical developments have shown that Hlinka's position turned out to be correct and therefore exemplary:

Lesson one: not to fear to suffer for the nation and to bear wrongs, burdens and persecution. All of these pass, as they passed in Hlinka's case. Only the truth remains eternal. And for this truth existence and the need for national rights is necessary. This is the thirty-year dogma of our party, sanctified by Hlinka's suffering and pains. ${ }^{18}$

Despite it being an era of intense Magyarization, Hlinka did not doubt that the Slovaks would finally gain the right to their own existence.

From the start, Černová was associated with Hlinka, and Hlinka with Černova. Even the verdict in the Černová trial showed that the germ of the whole insurrection and violence could be found in Hlinka's personality:

He was aware of the affection his countrymen had for his person and he knew of the unbridled hatred of a significant part of them to anything that related to Magyarization and which nurtured and stirred up their exaggerated nationalist sensibilities. He whipped up these sensibilities both in Černova and in Ružomberok... He united their national convictions with their religious feelings. And the people, brought to such a mental state by Hlinka, fanatically devoted themselves to his service and by common resolution declared that they would stop the consecration of the church even at the cost of their own blood. ${ }^{19}$

\section{PROJECTION OF ANDRE] HLINKA INTO THE HISTORICAL MEMORY FOLLOWING THE ESTABLISHMENT OF THE CZECHOSLOVAK REPUBLIC}

The founding of the Czechoslovak Republic had a huge impact on Andrej Hlinka's life. During the First World War he influenced Slovak policy on a common state of Czechs and Slovaks. Through his historic statement, Hlinka put an indelible stamp on political developments:

The Habsburgs were long enemies of our nation and of the Slavs. We would never have achieved the sought-after goal by ignoring this. This is a time for

\footnotetext{
17 Sidor, K., “Uväznenie Andreja Hlinku pred 30 rokmi”, Slovák, 28 Jun 1936 (18), No. 147, p. 1.

18 Sidor, K., “Uväznenie Andreja Hlinku pred 30 rokmi”, Slovák, 28 Jun 1936 (18), No. 147, p. 1.

19 Sidor, K., Černová (1907-1937), Bratislava 1937, p. 74.
} 
action. It is definitely urgent for us to say if we are going forward with the Hungarians or with the Czechs. We cannot avoid the question, let's say it openly, that we are in favour of a Czech-Slovak orientation. The thousandyear marriage with the Hungarians has not worked out. We have to split up. ${ }^{20}$

Hlinka unilaterally supported the idea of Czech-Slovak statehood, but with the condition of a parity representation of both the Slovak and the Czech nations, and so right from the emergence of the new state he became actively engaged in political life. He was responsible for breathing new life into the Slovak Catholic political movement, which resulted in the renewal of the Slovak People's Party in 1918, with Hlinka at its head. It was this that won him the primary position in the Slovak Catholic movement.

Political developments after the founding of the Czechoslovak Republic, however, continued in conflict with the original plans for the equality of the Slovak and Czech nations in the new state, which led the representatives of Slovak Catholicism to adopt a program of autonomy for Slovakia within the new state. Shortly after its creation, the Slovak People's Party gained the decisive support of the Slovak population and thus reinforced Hlinka's position as the leader of the nation and the most important living Slovak, a stable figure in the nation's historical memory. The process of anchoring Hlinka's memory in the social and historical consciousness of this period gained a new dimension in the Slovak Catholic community. It raised the respect of his contemporaries for Hlinka and spotlighted his share in the liberating of the Slovak nation from the repressive Hungarian domination. Also expectations of successfully implementing the Slovak autonomy program within the CSR were placed at his door. The celebration of his sixtieth birthday and the twentieth anniversary of the Černova tragedy added to the hyperbole around Hlinka's person in the first part of the 1920s. The Catholic press in particular dedicated a lot of space to both occasions.

The popular press devoted special attention to the 60th birthday of A. Hlinka. On that occasion several newspaper articles were published glorifying Hlinka's personality, further contributing to the fixing of his place in the Slovak historical consciousness. According to the authors of articles in the Slovák, this anniversary was celebrated by the "greatest Slovak, the father and the leader of the Slovak nation." For the Slovak Catholic public, Hlinka represented simply "the martyr for Slovak truth, the leader and the future liberator of the Slovak nation... Andrej Hlinka is a martyr, a leader and a liberator in one person." ${ }^{\text {"21 }}$ The celebratory articles idealized Hlinka's character and his personality. They emphasized that he had stood by the Slovaks in the difficult cir-

20 Quoted according to: R. Letz, Slovenské dejiny IV, 1914-1938, Bratislava 2010, p. 69.

21 B. C. Astor, “Ave Hlinka”, Slovák, 27 Sep 1924 (6), No. 221, p. 2. 
cumstances of his suspension and did not hesitate to stand up against the authorities in defence of the Slovaks in spite of the threat to his own existence:

His noble, heroic soul did not shrink from the prison garb nor from the dim cell of the prison, where he heroically suffered for his nation. And when he was released, as if on command almost the whole of the nation stood with him, recognizing their leader on the thorny road to liberty, seeing in him the future liberator of the Slovak nation. ${ }^{22}$

Hlinka did not only assist in the freeing of the Slovaks, but even led them back to the Catholic faith at a time when godlessness and moral degradation threatened them: "In the difficult times of the struggle divine Providence sent him, as it sends a leader in moments of hard experiences to every nation which does not deserve to be swept off the face of the earth." ${ }^{23}$ Hlinka found himself in the position of the only redeemer of the Slovak nation. He had become the one to bring new life to the Slovaks:

The dawning of new life already covers the period of stagnation in the veil of the past. Now the meadows are greening, now the flowers of Christian-Catholic awareness and Slovak national pride are blooming, Slovakia is rising up ... and all of this to the deserts of the blessed activities of our great, ennobled Hlinka. And therefore we, as proud, self-confident Slovaks, celebrate him. ${ }^{24}$

Hlinka's services for the Slovak nation are for other ordinary Slovaks unachievable and invaluable: “The pen does not suffice, words are weak; how can Hlinka's great work be suitably appreciated? How can the thousand merits of Andrej Hlinka be named, that inextinguishable clean stream flowing from his ennobled heart, flowing from love of God and of the nation that flows in the valley of the history of the Slovak nation?"25

The Roman Catholic priest Štefan Mnohel' compared Hlinka to the famous Czech politician, the organizer of Czech political and social life, the successor to F. Palacky, F. L. Rieger:

The famed Rieger said at the beginning of the national revival that the entire national Czech camp could fit under one leafy linden tree. Our Slovak Rieger, the rouser of the nation Andrej Hlinka ... did not even have enough followers to fit under a slender linden - we were not there and that he has the whole nation around him today is due to his work. ${ }^{26}$

\footnotetext{
22 B. C. Astor, “Ave Hlinka”, Slovák, 27 Sep 1924 (6), No. 221, p. 2.

23 B. C. Astor, “Ave Hlinka”, Slovák, 27 Sep 1924 (6), No. 221, p. 2.

24 B. C. Astor, “Ave Hlinka”, Slovák, 27 Sep 1924 (6), No. 221, p. 2.

25 B. C. Astor, “Ave Hlinka”, Slovák, 27 Sep 1924 (6), No. 221, p. 2.

26 Š. Mnohel', “Slávime”, Slovák, 27 Sep 1924 (6), No. 221, p. 2.
} 
According to this author, it was Andrej Hlinka who brought sacrifices to the altar of the Slovak nation.

Another populist periodical, Slovenská pravda, a political, social and economic weekly from eastern Slovakia, on Hlinka's 60th birthday attempted an analysis of those of Hlinka's character traits where "we see in his character something exceptional and unusual, something special - Hlinkaesque." ${ }^{27}$ The author of the famed article, writing under the pseudonym Pravdomil, knew Hlinka personally and emphasized those characteristics thanks to which he had become exceptional and so had managed to implant himself as the leading personality of the Slovak nation:

I do not hesitate to say that for me Hlinka is a mystery, and this because those universal characteristics which are usually found in hundreds of people are concentrated as one in him... Is he a gifted speaker? He is. But the peculiarity and the specialness of his rhetorical art resides in the fact that he most fires the souls of his listeners when he is not trying to. Is he a wonderful writer? He is. Just that even if many other move their pens beautifully, he ploughs so deeply into the heart like no-one else. ${ }^{28}$

The article's author reflects on how Hlinka managed to be successful in politics too:

Is he a dexterous politician? Not really, they say. And this because he relies on a strategy of principles today uncommon: we have agreed that we will agree. He has his own political credo which he believes so strongly that he is a fanatic for his own political convictions and therefore hates compromise, because he fears that in negotiation the truth will suffer, to his detriment. This is why Andrej Hlinka is a strange and stubborn politician, on one side beloved and on the other side unpopular and feared. ${ }^{2}$

An integral component of Hlinka's image in the consciousness of his contemporaries was his martyr-like dedication to the Slovak nation:

Has he suffered much for his nation? - This is precisely his original specialty. While others too have been rewarded by prison and persecution for their patriotism - not many have borne suffering with such steadfastness as him. For Hlinka prison is not punishment but a new rousing for the cause of the dear nation.

The author also draws attention to Hlinka's exceptional, otherworldly, appearance as he appeared in the eyes of his peers:

The exceptional and ethereal nature of Hlinka's person will only be understood when we realize that he lives only for us, for his Slovak people. This can only happen when our people perceive him as our own, indeed as the property of everyone. 
Hlinka's personality and Hlinka's life thus became identified with the past and the future of the Slovak nation:

Our nation sees itself in Andrej Hlinka, so that his bitter past and struggling present have become also the past and the present of the whole Slovak nation. And what is remarkable about Hlinka is that he cannot be distinguished apart from the nation. Hlinka's fate is this: to remain until his death just a Ružomberok parish priest, because as such he has become the father of the nation. Whoever would desire to make of Andrej Hlinka something other than he is today would thereby destroy in him the ideal of the nation." 30

The celebrations on the occasion of his 60th birthday, which took place in Ružomberok in September 27-28, 1924, made a significant contribution to rooting Andrej Hlinka in the historical memory. During its course expressions of sympathy to Hlinka and uncritical admiration for his personality came to the fore, along with praise for his exceptionality and his services to the church and to the nation. The Slovak People's Party daily, Slovák, gave detailed reports on the ceremonious occasion. In the opening lines of the article, the singularity of the celebrant was mentioned and then it went on to designate him the greatest of the Slovaks. This status was confirmed by greetings from the entire Slovak nation, from the British Consul in Bratislava, and most treasured of all, the congratulations of Pope Pius XI, transmitted by the Vatican's Prague nuncio. ${ }^{3}$

In this period Hlinka definitively fixed himself in the minds of his contemporaries as the Father of the Slovak nation through the wholehearted admiration of not only the Catholic but also a section of the Evangelic public, as Národnie noviny expressed it in the words of the political scientist Ludovit Bazovský. ${ }^{32}$ Again on the occasion of Hlinka's jubilee, Bazovský too emphasized Hlinka's uncommonness and exceptionality while classing him among the giants of the Slovak nation: "A dauntless national personality in conjunction with a deep religious faith, providing a fascinating magnetic example for every Slovak minister, even for the Evangelic." ${ }^{33}$ For Bazovský, Hlinka combined the national identity with a religious identity, since "Hlinka as a Roman Catholic priest never forgot that he was a Slovak and as a Slovak never forgot that he was a Roman Catholic priest. ${ }^{34}$ In the Austro-Hungarian era, Hlinka was above all a fighter for the right of the Slovak nation to self-determination and a protagonist for the idea of a joint Czech-Slovak state, but the foundation of the new republic for him represented a disappointment. Bazovský even calls Hlinka the first Slovak political prisoner in the Czechoslovak Republic, since in 1919 he was imprisoned for a secret

30 Pravdomil, “Náš Andrej Hlinka”, Slovenská pravda. 28 Sep 1924 (5), No. 40, p. 1.

31 “Oslavy Andreja Hlinku v Ružomberku”, Slovák, 30 Sep 1924 (6), No. 222, p. 1-2.

32 L. Bazovský, "Andrej Hlinka 60-ročný”, Národnie noviny, 28 Sep 1924 (55), No. 76, p. 1.

33 L'. Bazovský, "Andrej Hlinka 60-ročný”, Národnie noviny, 28 Sep 1924 (55), No. 76, p. 1.

34 L. Bazovský, "Andrej Hlinka 60-ročný”, Národnie noviny, 28 Sep 1924 (55), No. 76, p. 1. 
mission to the Paris Peace Conference together with F. Jehlička and Š. Mnohel', where he went to present the issue of the autonomy of Slovakia at the international forum. ${ }^{35}$

The coming of his 60th birthday represented a shift in the perception of Andrej Hlinka by the Slovak public. In the historical memory of chiefly the Catholic element in the society, Hlinka had become the greatest living Slovak and the Father of the Slovak nation. He was no longer just a fighter for Slovak freedom with the aura of a martyr against the Hungarian ruling class, but he had become a fighter for the preservation of the Slovak national character in the first Czechoslovak Republic.

\section{[REATION OF THE CULT OF ANDRE] HLINKA AND ITS PROJECTION INTO THE HISTORICAL MEMORY OF THE 19305}

After the formation of the Czechoslovak Republic, admiration for Hlinka began to take on the hallmarks of a cult. Both the constant emphasizing of his exceptionality and uniqueness and the critical appraisals by his political opponents led to the formation and expansion of his cult. This well served Hlinka in acquiring and maintaining political allies, and at the same time created a counterweight to the growing cult of the Republic's president, T. G. Masaryk. Undermining Masaryk's cult by building a cult to Hlinka represented a relatively successful attempt to set a conservative Catholic priest, a modest and unassuming man of the people, a national leader and a martyr, against the anti-Catholic, liberal and 'free-thinking' Masaryk. ${ }^{36}$

A significant contribution to widening the Hlinka cult and securing his person in the memory of the Slovak society was offered by a further lifetime jubilee: Hlinka's 70th birthday. At this time when it was becoming ever more obvious that his life was coming to an end, his anniversary was marked by increased attention in the press. The People's Party publication, Slovák, published a special expanded edition dedicated to Hlinka and the celebrations, which were again planned in Ružomberok for the 2728 of September, 1934..$^{37}$ Hlinka's anniversary enabled the full reinforcement of his position as the leader of the Slovak nation.

The author of one of the celebratory articles pointed out that it was Hlinka alone who in 1918 prepared the path towards a better future for all members of the Slovak nation regardless of their religious affiliation. Since October 1918 Slovakia followed

35 L. Bazovský, "Andrej Hlinka 60-ročný”, Národnie noviny, 28 Sep 1924 (55), No. 76, p. 1.

36 R. Letz, "Osobnost' Andreja Hlinku”, R. Letz, P. Mulík et al., Pohl'ady na osobnost' Andreja Hlinku, Martin 2009, p. 18-19.

37 Slovák, 27 Sep 1934 (16), No. 219, p. 1-12. 
the route Hlinka laid out for it - the formation of the Czechoslovak Republic. Even in the hardest times, Hlinka never neglected the nation, quite the reverse. When it had become clear that the Prague government would not allow any sort of autonomy for the Slovaks, Hlinka personally went to Paris to fight for the nation in an international forum. By founding the Slovak People's Party, Hlinka made himself the architect of modern Slovak post-overthrow politics:

He put the contents into the political program in the concept of autonomy for Slovakia. He awoke the lively interest of a wide group in this idea. Throughout his life he never lost a fight because he led a fight for a concept, for an idea, and the fight for an idea always ends with its victory. ${ }^{38}$

During the celebrations, the bishop of Spiš, Ján Vojtaššák, also contributed to raising A. Hlinka's national importance by declaring that:

Hlinka will only be truly appreciated when he is no longer among the living. Nonetheless, all those who have the matters of the Slovak nation and its future close to their heart wish that Hlinka and his activities will still be for as long as possible a centre-point and subject for living public commentators. ${ }^{39}$

For another bishop, Jozef Čársky, Hlinka represented a strong personality who determined "the direction of the thoughts and actions of the nation". He possessed personal qualities thanks to which he became a singular and irreplaceable personality for the Slovak nation: "Gifted by God with external gifts: a fine posture, a caustic voice, captivating rhetoric, a clever wit, healthy humour, a good memory, narrative nimbleness, he electrifies and stirs the masses of the Slovak nation with the thought embodied in the slogan: for God and for the nation." ${ }^{40}$ In modern Slovak history, Hlinka is the most meaningful personality. Bishop Čársky as his greatest merit considers the fact that "he carried the national consciousness to the nationally most backward regions and, by rousing their Catholic conscience, halted the wave of faithlessness and ungodliness and so defended many religious values and prevented many evils."

The People's Party daily also informed its readers of the course of Hlinka's jubilee celebrations. On this occasion the town of Ružomberok lived only for the gala, which attracted a great number of people. The entire town was dressed up in their ceremonial clothes:

Whole Ružomberok today is basking in the light of the Hlinka celebrations.

Yesterday evening many of the guests arrived in Ružomberok. They came in

\footnotetext{
38 “Andrej Hlinka 70-ročný”, Slovák, 27 Sep 1934 (16), No. 219, p. 1.

39 J. Vojtaššák, “K jubileu Andreja Hlinku”, Slovák, 27 Sep 1934, (16), No. 219 , p. 3.

40 J. Čársky, "Silná osobnost”, Slovák, 27 Sep 1934 (16), No. 219, p. 2.

41 J. Čársky, “Silná osobnost”, Slovák, 27 Sep 1934 (16), No. 219, p. 2
} 
unprecedented numbers and unannounced, so their accommodation caused the organizers great worries... The whole of Ružomberok is decked out in flags, in the shop and house windows Hlinka's likeness is displayed, along with statuettes garlanded with flowers. ${ }^{42}$

Information on the running of the event made it clear that the birthday celebrations were honouring Slovakia's most significant figure, the leader of the nation. The Presidium, the deputies' and senators' clubs and the regional deputies of the Slovak People's Party under its chairman, Senator Jozef Buday made up the official part of the celebration. In his opening speech, Buday stated that "Hlinka may have his competitors in culture, industry, banking and elsewhere, but definitely not in politics." He repeatedly drew attention to the character of the celebrant when he noted that "Hlinka is a "man of principles and character." Other speakers did not forget to underline Hlinka's deserts in the emancipation of the Slovak nation back in the times of the existence of AustroHungary, and in the forming of the Slovaks into a modern nation: "...while long before the overthrow all the Slovaks of conviction could have fit under one linden-tree, due to the merits of Hlinka's work there is today not one linden which could cover such Slovaks with its leaves." ${ }^{\prime 3}$ The celebrations continued with the congratulations of the Slovak National Party delegation headed by Martin Rázusa. According to him, Hlinka was the person who had united all the Slovaks, "He is the stimulator and the guarantee that we need no longer regret the fate of our nation." ${ }^{34}$ Significant Slovakia-wide or local groups also made their appearance at the festivities, as well as guests from abroad who had come to congratulate Hlinka, such as the Polish delegation under the prelate Leopold Bilko. ${ }^{45}$ Worthy of note is that the Catholic priest Jozef Tiso, the leading representative of the People's Party, came to the Ružomberok celebrations to congratulate Hlinka. This future President of the wartime Slovak state praised above all Hlinka's traditionalism and his profession of "old and good Christian and national traditions," through which Hlinka "preserved the nation from falsehoods and from the downfall which threatened it from misleading innovations." 46

The projection of Andrej Hlinka into the historical memory of Slovakia's Catholic society even during his lifetime clearly confirms that it was an expansive and disparate

\footnotetext{
42 “Hlinkove oslavy v Ružomberku”, Slovák, 28 Sep 1934 (16), No. 220, p. 1.

43 Spoločné zasadnutie l'udových klubov, „Slovák“, 28. 9. 1934, r. 16, nr. 220, s. 1.

44 Spoločné zasadnutie l'udových klubov, „Slovák“, 28. 9. 1934, r. 16, nr. 220, s. 1.

45 Spoločné zasadnutie l'udových klubov, „Slovák“, 28. 9. 1934, r. 16, nr. 220, s. 1.

46 Holdujúca reč posl. dr. Tisu, „Slovák“, 30. 9. 1934, r. 16, nr. 221, s. 2.
} 
process. The anchoring of Andrej Hlinka in the consciousness of the Slovak society went through a number of changes. In the period of the existence of the Austro-Hungarian Empire, at a time of increasing Magyarization, Hlinka, as a result of the tragedy in Černova, became a symbol of the struggle of the Slovaks for national freedom. He gained the aureole of a martyr fighting for the right of the Slovak nation for its separate existence. After the foundation of the Czechoslovak Republic, Hlinka became the leader and the Father of the Slovak nation, fighting for the greater freedom of the Slovak nation, this time in the form of autonomy within the new state. In the 1930s it was primarily his followers who nurtured the cult to Hlinka's person, which flourished at the time of the celebration of his seventieth birthday. Hlinka was by this time perceived as the greatest living Slovak and the man who had the greatest merit in the reforming of the Slovaks into a modern nation.

\section{TRANSLATION: EVO SCIRANKOVÁ}

\section{BIBLIOGRAPHY:}

Astor B. C., Ave Hlinka, „Slovák”, 27 Sep 1924 (6), Nr. 221

Bazovský L'., Andrej Hlinka 60-ročný, „Národnie noviny”, 28 Sep 1924(55), Nr. 76

Čársky J., Silná osobnost', Slovák, 27 Sep 1934 (16), No. 219

Hlinka A., Na černovskom cintoríne, „Slovák”, 27 Oct 1923(5), Nr. 234

Hlinka A., Otvorený list na dr. Augustína Rátha, rektora bratislavskej univerzity, „Slovák”, 18 Feb 1922(4), Nr. 40

Holec R., Tragédia v Černovej a slovenská spoločnost', Martin 1997

J. Vojtaššák, Kjubileu Andreja Hlinku, „Slovák”, 27 Sep 1934, (16), Nr. 219

Kolísek A., Andrej Hlinka, Bratislava 1924

Kováč D., Charizma, triumfy a krok vedla. Súdne procesy Andreja Hlinku, Storočie procesov, Bratislava 2013

Letz R., Slovenské dejiny IV, 1914-1938, Bratislava 2010

Macho P., Reflexia Andreja Hlinku v protestantskom prostredí, Milan Rastislav Štefánik v hlavách a v srdciach. Fenomén národného hrdinu v historickej pamäti, Bratislava 2011

Mnohel' Š., Slávime, „Slovák”, 27 Sep 1924 (6), Nr. 221

R. Letz, Osobnost' Andreja Hlinku [w:] R. Letz, P. Mulík et al., Pohl'ady na osobnost' Andreja Hlinku, Martin 2009

Rázusa Martin, Spoločné zasadnutie luudových klubov, „Slovák“, 28. 9. 1934, r. 16, nr. 220

Seton-Watson R. W., Nábožensko-cirkevný problém, „Lidové noviny“, (32), 27 Jan 1924 s. 49

Sidor K., Andrej Hlinka, Bratislava 1924

Sidor K., Černová (1907-1937), Bratislava 1937

Sidor K., Uväznenie Andreja Hlinku pred 30 rokmi, „Slovák”, 28 Jun 1936(18), Nr. 147

Štefánik M. R., A. Hlinka v básnických a komemoratívnych textoch. Historická osobnost' ako národný symbol a jeho štylizácia, „Studia Academica Slovaca”, 2005(34), s. 367-395

Tiso Jozef, Holdujúca reč posl. dr. Tisu, „Slovák“, 30. 9. 1934, r. 16, nr. 22

Topolski J., O pojęciu bohaterów w historii. “Przegląd Humanistyczny”, 1996 (40), Nr. 1 (334), p. 19-26 